\title{
Study the Role of Lung Ultrasound in Assessment of Subclinical Fluid Overload in Maintenance Hemodialysis Patients with Intra-Dialytic Hypertension
}

\author{
Said S. A. Khamis' ${ }^{1}$ Yassein S. Yassein'1, Khaled M. A. El Zorkany', Waleed A. Mousa ${ }^{2}$, \\ Abdellatif S. A. Kora ${ }^{3 *}$, Ahmed Ragheb ${ }^{1}$
}

${ }^{1}$ Department of Medicine, Faculty of Medicine, Menoufia University, Shibin El-Kom, Egypt

${ }^{2}$ Department of Radiology, Faculty of Medicine, Menoufia University, Shibin El-Kom, Egypt

${ }^{3}$ Department of Medicine, Shibin El-Koom Teaching Hospital, Shibin El-Kom, Egypt

Email: ${ }^{*} \operatorname{logyn} . k o r a @ y a h o o . c o m$

How to cite this paper: Khamis, S.S.A., Yassein, Y.S., El Zorkany, K.M.A., Mousa, W.A., Kora, A.S.A. and Ragheb,, A. (2020) Study the Role of Lung Ultrasound in Assessment of Subclinical Fluid Overload in Maintenance Hemodialysis Patients with Intra-Dialytic Hypertension. Open Journal of Nephrology, 10, 199-211.

https://doi.org/10.4236/ojneph.2020.103019

Received: June 7, 2020

Accepted: July 5, 2020

Published: July 8,2020

Copyright $\odot 2020$ by author(s) and Scientific Research Publishing Inc. This work is licensed under the Creative Commons Attribution International License (CC BY 4.0).

http://creativecommons.org/licenses/by/4.0/

\begin{abstract}
Objectives: To elucidate the role of lung ultrasound in assessment of subclinical fluid overload in hemodialysis (HD) patients. Background: Volume overload has a significant role in HD patients with difficult blood pressure control. The clinical evaluation of fluid status is challenging and has poor diagnostic accuracy. Extravascular lung water (ELW) represents an important element of body fluid volume. Lung ultrasound (LUS) is increasingly used for ELW assessment through the analysis of B-lines artifacts. Methods: Eighty-eight HD patients were followed up prospectively. Patients were divided into 3 groups according to the changes of systolic blood pressure (SBP) during HD sessions. Group (1): patients with intra-dialytic hypertension ( $\mathrm{n}=$ 12), group (2): patients with intra-dialytic hypotension $(\mathrm{n}=28)$ and group (3): patients with no significant blood pressure variabilities $(n=48)$. Numbers of B-lines were measured by LUS and IVC diameters were measured pre and post-dialysis. In addition, Endothelin-1 (ET-1) and other routine laboratory tests were done. Results: There were significant increases in the number of B-lines and IVC diameter pre and post-dialysis in group (1) compared to the other two groups. There was significant decrease in post dialysis IVC diameter but not the number of B-lines in group (2) compared with the other two groups. ET-1 level was significantly increased in group 1 compared to the other two groups. There was a statistically significant positive correlation between the pre-dialysis number of B-lines and ET-1. Conclusion: Lung ultrasound can be considered a sensitive and specific modality for volume assessment in HD patients especially with intra-dialytic hypertension. We recommend serial LUS as a part of management in this group of patients.
\end{abstract}




\section{Keywords}

Intra-Dialytic Hypertension, Volume Assessment, Lung Ultrasound, B-Lines

\section{Introduction}

Initial research in intra-dialytic hypertension focused on the potential biologic mechanisms to explain the acute rise in blood pressure, particularly the role of endothelin-1 (ET-1). More recent research has generated an in-depth characterization of the patient phenotype from epidemiologic studies, and smaller case-control studies have explored new mechanisms. Although the role of ET-1 continues to be revisited, other mechanisms including the role of dialysate sodium and extracellular osmolarity have been explored. There is a strong evidence that extracellular volume excess is a consistent phenotype in patients with intra-dialytic hypertension [1].

Patients with persistent intra-dialytic hypertension have been characterized as patients with lower baseline weight and small inter-dialytic weight gain (IDWG) that may result in masked chronic extracellular volume excess. Multiple studies using bioimpedance spectroscopy have demonstrated a consistent association between intra-dialytic hypertension and extracellular volume excess after dialysis. Removing a volume of fluid during dialysis equivalent to the IDWG ensures fluid balance but does not necessarily eliminate extracellular volume excess. Compared to most HD patients, patients with intra-dialytic hypertension have smaller IDWG and have lower pre-dialysis blood pressure [2].

Subclinical fluid overload was defined as normovolemia by clinical assessment, but with positive over hydration as measured by Lung Ultrasound (LUS) [3]. Although LUS conventionally focuses on the evaluation of anatomic images of pleural effusion, pleural masses, and lung consolidations, this technique is increasingly used for extravascular lung water (ELW) assessment through the analysis of B-line artifacts [4].

\section{Patient and Methods}

This prospective study was carried out on a total number of $88 \mathrm{HD}$ patients in Menoufia University Hospital from September 2019 to February 2020. The study followed the ethical standards of the hospital and was approved by the ethical committee. Informed consents were obtained from all patients. We included patients with at least three months duration of $\mathrm{HD}$, thrice per week, four hours duration, aged between eighteen and seventy-five years. We excluded pregnant and lactating females, patients with confirmed malignancy and patients with heart failure NYHA class III \& class IV. We also excluded patients in whom we cannot measure blood pressure from upper limbs. Patients were divided into three groups according to the blood pressure variability during dialysis; group (1) included 12 patients with intra-dialytic hypertension, group (2) included 28 
patients with intra-dialytic hypotension and group (3) included 48 patients with no blood pressure variabilities.

For more extensive study of the role of LUS in evaluation of volume status and prediction of intra-dialytic hypertension, we aimed to decrease the number of pre-dialysis B-lines in group (1) patients through managing their DBW, UF volume, fluid intake and medications. After decreasing the number of pre-dialysis B-lines below the cut-off level $(<5)$ we compared the intra-dialytic BP changes and IVC diameters of those patients with their previous results (group $1^{\text {After }}$ and $1^{\text {Before }}$ ).

We defined intra-dialytic hypertension as a rise in SBP during or immediately after HD session of $\geq 10 \mathrm{mmHg}$ in at least four of six consecutive dialysis sessions [5]. Intra-dialytic hypotension was defined as drop in SBP $\geq 20 \mathrm{mmHg}$ during or immediately after HD session with symptoms that include: abdominal discomfort; yawning; sighing; nausea; vomiting; muscle cramps; restlessness; dizziness or fainting and anxiety [6].

All patients were subjected to the following: Full history with stress on drug history, symptoms of volume overload or hypovolemia. Pre and post-dialysis body weight, UF volume \& rate were estimated for all patients. Blood pressure was checked pre, during and post-dialysis while patients were comfortable in bed not in pain with arm supported. HD procedure was standardized for all the patients. Routine laboratory investigations including $\mathrm{CBC}$, urea, creatinine, albumin and ET-1 were done pre-dialysis.

Inferior vena cava (IVC) diameter was measured within $1 \mathrm{~cm}$ from the junction of IVC and superior hepatic veins, pre and post-dialysis by the same operator in a mid-week HD session. LUS was done pre and post-dialysis by the same operator in a mid-week HD session using portable ultrasound scanner (DP 20) 2 - $5 \mathrm{MHz}$. We divided chest examination to anterior chest wall from midline to anterior axillary line and lateral chest wall from anterior axillary line to posterior axillary line. Each part was subdivided into upper and lower zones, upper zone includes $2^{\text {nd }}, 3^{\text {rd }}$ and $4^{\text {th }}$ intercostal spaces (on the right side includes also $5^{\text {th }}$ intercostal space). Lower zone included intercostal spaces below $4^{\text {th }}$ space on the left side and $5^{\text {th }}$ space on the right side.

\section{Statistical Evaluations}

Clinical and laboratory data were recorded on a report form. These data were tabulated and analyzed using the computer program Microsoft Office 2003 (excel) and Statistical Package for the Social Sciences (SPSS version 20.0) (2013; IBM Corp., Chicago, Illinois, USA). Descriptive data and Descriptive statistics were calculated for the data in the form of: Mean and standard deviation (Mean $\pm \mathrm{SD}$ ) the following tests were used to test differences for significance; difference and association of qualitative variables by Chi square test $\left(\mathrm{X}^{2}\right)$. Differences between quantitative independent groups by $t$ test, multiple by ANOVA, correlations by Pearson's correlation. For non-parametric data quantitative independent groups by Mann-Whitney test, multiple by Kruskal Wallis test, correlations by Spearman's correlation. Receiver operating characteristic (ROC) curve was 
used to evaluate the diagnostic performance of LUS in volume assessment. P value $<0.05\left({ }^{*}\right)$ was set for significant results $\&<0.01\left({ }^{*}\right)$ was set for highly significant results.

\section{Results}

Demographic data and anthropometric measures of the studied groups revealed no significant differences as regard age and sex. There were significant increases in BMI, DBW, IDWG and UF volume in group (2) compared to other two groups ( $\mathrm{p}<0.001)$ and in group (3) compared to group $(1)(\mathrm{p}<0.001)$ except for DBW (Table 1).

Laboratory investigations showed significant decrease in serum albumin and creatinine in group (1) compared to other two groups $(\mathrm{p}<0.001)$ with no significant difference between groups (2) and (3). ET-1 was significantly increased in group (1) compared to groups (2) and (3) $(\mathrm{p}<0.001)$ with no significant difference between groups (2) and (3) (Table 1).

Comparison between the different groups showed a significant increase in pre-dialysis IVC diameter in group (1) compared to the other two groups ( $\mathrm{p}<$ 0.001 ) with no significant difference between groups (2) and (3). There was a significant increase in post-dialysis IVC diameter in group (1) compared to the other two groups $(\mathrm{p}<0.001)$ and in group $(3)$ compared to group $(1)(\mathrm{p}<0.001)$ (Table 2).

There was a statistically significant increase in the number of pre-dialysis B-lines in group (1) compared to groups (2) and (3) ( $p<0.001)$ and in group (2) compared to group $(3)(\mathrm{p}<0.05)$. There was a statistically significant increase in the number of post-dialysis B-lines in group (1) compared to groups (2) and (3) $(\mathrm{p}<0.001)$ with no significant difference between groups (2) and (3). There was a statistically significant increase in the change of the number of B-lines in group (1) compared to groups (2) and (3) $(\mathrm{p}<0.001)$ and in group (2) compared to group (3) $(\mathrm{p}<0.05)($ Table 3$)$.

There were no statistically significant correlations between the pre-dialysis number of B-lines and Weight, $\mathrm{Hb}, \mathrm{Kt} / \mathrm{V}$ or SBP. On the other hand, there were statistically significant negative correlations between pre-dialysis B-lines and BMI, creatinine, albumin, IDWG and UF volume $(\mathrm{p}<0.001)$. There was a statistically significant positive correlation between the pre-dialysis number of B-lines and IVC diameter \&ET-1 ( $<$ 0.001) (Table 4 and Figures 1-3).

ROC curve analysis of the number of pre-dialysis B-lines for prediction of intra-dialytic hypertension showed that the best cut-off value was $\geq 5$ with $91.7 \%$ sensitivity and $100 \%$ specificity $(\mathrm{p}<0.001)$ (Table 5 and Figure 4 ).

After reaching pre-dialysis number of B-lines less than the previous cut-off value $(<5)$, re-evaluation of group (1) patients demonstrated that 9 patients out of the $12(75 \%)$ did not suffer from intra-dialytic hypertension. We also, found significant reductions in the pre and post-dialysis IVC diameters in group ( $\left.1^{\text {After }}\right)$ compared to group (1 $\left.{ }^{\text {Before }}\right)$ (Table 6). 
Table 1. Demographic and laboratory data of the studied groups.

\begin{tabular}{|c|c|c|c|c|c|c|c|c|c|}
\hline \multirow[t]{2}{*}{ Variable } & \multicolumn{2}{|c|}{$\begin{array}{l}\text { Group } 1 \\
(\mathrm{n}=12)\end{array}$} & \multicolumn{2}{|c|}{$\begin{array}{l}\text { Group } 2 \\
(\mathrm{n}=28)\end{array}$} & \multicolumn{2}{|c|}{$\begin{array}{l}\text { Group } 3 \\
(n=48)\end{array}$} & F & $P$ value & L.S.D. \\
\hline & \multicolumn{8}{|c|}{ Age (Years) } & \\
\hline Mean \pm SD & \multicolumn{2}{|c|}{$48.33 \pm 10.81$} & \multicolumn{2}{|c|}{$56.07 \pm 11.72$} & \multicolumn{2}{|c|}{$53.48 \pm 13.09$} & \multirow{2}{*}{1.79} & \multirow{2}{*}{0.172} & \\
\hline Range & \multicolumn{2}{|c|}{$36-70$} & \multicolumn{2}{|c|}{$36-73$} & \multicolumn{2}{|c|}{$20-72$} & & & \\
\hline Sex & No. & $\%$ & No. & $\%$ & No. & $\%$ & $x^{2}$ & & \\
\hline Female & 2 & 16.7 & 10 & 35.7 & 21 & 43.8 & & & \\
\hline Male & 10 & 83.3 & 18 & 64.3 & 27 & 56.2 & 3.06 & 0.217 & \\
\hline
\end{tabular}

Dry body weight $(\mathrm{Kg})$

\begin{tabular}{ccccccc}
\hline Mean \pm SD & $75.75 \pm 5.86$ & $83.82 \pm 7.79$ & $78.40 \pm 7.54$ & & $P_{1}=\mathbf{0 . 0 0 2 *}$ \\
Range & $62-85$ & $68-103$ & $60-90$ & 6.746 & $\mathbf{0 . 0 0 2}^{*}$ & $\mathrm{P}_{2}=0.273$ \\
& & & & & $\mathrm{P}_{3}=\mathbf{0 . 0 0 3}^{*}$
\end{tabular}

$\operatorname{BMI}\left(\mathrm{Kg} / \mathrm{m}^{2}\right)$

\begin{tabular}{|c|c|c|c|c|c|c|}
\hline $\begin{array}{c}\text { Mean } \pm \text { SD } \\
\text { Range }\end{array}$ & $\begin{array}{c}23.13 \pm 1.71 \\
21-26.3\end{array}$ & $\begin{array}{c}27.01 \pm 2.00 \\
23.5-30.8\end{array}$ & $\begin{array}{c}25.44 \pm 2.06 \\
20-29.0\end{array}$ & 16.37 & $0.001^{* *}$ & $\begin{array}{l}P_{1}=0.000^{* *} \\
P_{2}=0.000^{* *} \\
P_{3}=0.000^{* *}\end{array}$ \\
\hline \multicolumn{7}{|c|}{ IDWG (kg) } \\
\hline $\begin{array}{c}\text { Mean } \pm \text { SD } \\
\text { Range }\end{array}$ & $\begin{array}{c}2.88 \pm 0.23 \\
2.5-3\end{array}$ & $\begin{array}{c}4.61 \pm 0.58 \\
4-6\end{array}$ & $\begin{array}{c}3.92 \pm 0.73 \\
2-5\end{array}$ & 31.459 & $0.001^{* *}$ & $\begin{array}{l}P_{1}=0.000^{* *} \\
P_{2}=0.000^{* *} \\
P_{3}=0.000^{* *}\end{array}$ \\
\hline
\end{tabular}

UF volume (liter)

\begin{tabular}{|c|c|c|c|c|c|c|}
\hline $\begin{array}{c}\text { Mean } \pm \text { SD } \\
\text { Range }\end{array}$ & $\begin{array}{c}2.86 \pm 0.26 \\
2.3-3\end{array}$ & $\begin{array}{c}4.09 \pm 0.33 \\
3.5-4.5\end{array}$ & $\begin{array}{c}3.62 \pm 0.59 \\
2-4.5\end{array}$ & 27.028 & $0.001^{* *}$ & $\begin{array}{l}P_{1}=0.000^{* *} \\
P_{2}=0.000^{* *} \\
P_{3}=0.000^{* *}\end{array}$ \\
\hline \multicolumn{7}{|c|}{$\mathrm{HB}(\mathrm{gm} / \mathrm{dl})$} \\
\hline $\begin{array}{c}\text { Mean } \pm \text { SD } \\
\text { Range }\end{array}$ & $\begin{array}{c}9.70 \pm 0.88 \\
8.4-11\end{array}$ & $\begin{array}{c}10.38 \pm 1.44 \\
7.9-13\end{array}$ & $\begin{array}{c}10.27 \pm 1.42 \\
7.8-13\end{array}$ & 1.071 & 0.347 & \\
\hline
\end{tabular}

\begin{tabular}{|c|c|c|c|c|c|c|}
\hline \multicolumn{7}{|c|}{ Albumin (gm/dl) } \\
\hline $\begin{array}{c}\text { Mean } \pm \text { SD } \\
\text { Range }\end{array}$ & $\begin{array}{c}2.77 \pm 0.38 \\
2.20-3.50\end{array}$ & $\begin{array}{l}3.61 \pm 0.43 \\
2.80-4.20\end{array}$ & $\begin{array}{l}3.57 \pm 0.41 \\
2.80-4.30\end{array}$ & 20.419 & $0.001^{* *}$ & $\begin{array}{c}P_{1}=0.000^{* *} \\
P_{2}=0.000^{* *} \\
P_{3}=0.660\end{array}$ \\
\hline \multicolumn{7}{|c|}{ Creatinine (mg/dl) } \\
\hline $\begin{array}{c}\text { Mean } \pm \text { SD } \\
\text { Range }\end{array}$ & $\begin{array}{c}5.27 \pm 0.51 \\
4.50-6\end{array}$ & $\begin{array}{c}7.14 \pm 0.88 \\
5.5-9\end{array}$ & $\begin{array}{c}7.02 \pm 0.75 \\
5-8.5\end{array}$ & 28.395 & $0.001^{* *}$ & $\begin{array}{c}\mathrm{P}_{1}=0.000^{* *} \\
\mathrm{P}_{2}=0.000^{* *} \\
\mathrm{P}_{3}=0.512\end{array}$ \\
\hline \multicolumn{7}{|c|}{ Endothelin-1 (pg/ml) } \\
\hline $\begin{array}{c}\text { Mean } \pm \text { SD } \\
\text { Range }\end{array}$ & $\begin{array}{c}1136.25 \pm 62.35 \\
1020-1200\end{array}$ & $\begin{array}{c}685.71 \pm 100.74 \\
500-850\end{array}$ & $\begin{array}{c}682.92 \pm 114.73 \\
500-870\end{array}$ & 96.338 & $0.000^{* *}$ & $\begin{aligned} P_{1} & =0.000^{* *} \\
P_{2} & =0.000^{* *} \\
P_{3} & =0.911\end{aligned}$ \\
\hline
\end{tabular}

${ }^{*}$ significant if $\mathrm{P}<0.05,{ }^{*}$ highly significant if $\mathrm{P}<0.01, \mathrm{~F}$ : ANOVA test, LSD (least significant difference): $\mathbf{P}_{1}$ : Comparison between group 1 and 2, $\mathbf{P}_{2}$ : Comparison between group 1 and 3, $\mathbf{P}_{3}$ : Comparison between group 2 and 3. 
Table 2. Comparison of the IVC diameter changes in the studied groups.

\begin{tabular}{|c|c|c|c|c|c|c|}
\hline Variable & $\begin{array}{l}\text { Group } 1 \\
(n=12)\end{array}$ & $\begin{array}{l}\text { Group } 2 \\
(n=28)\end{array}$ & $\begin{array}{l}\text { Group } 3 \\
(n=48)\end{array}$ & F & $P$ value & L.S.D. \\
\hline \multicolumn{7}{|c|}{ pre IVC $(\mathrm{cm})$} \\
\hline $\begin{array}{c}\text { Mean } \pm \text { SD } \\
\text { Range }\end{array}$ & $\begin{array}{c}2.16 \pm 0.14 \\
2.0-2.4\end{array}$ & $\begin{array}{c}1.83 \pm 0.12 \\
1.6-2.0\end{array}$ & $\begin{array}{c}1.81 \pm 0.08 \\
1.6-1.9\end{array}$ & 56.328 & $0.000^{* *}$ & $\begin{array}{c}\mathrm{P}_{1}=0.000^{* *} \\
\mathrm{P}_{2}=0.000^{* *} \\
\mathrm{P}_{3}=0.416\end{array}$ \\
\hline \multicolumn{7}{|c|}{ Post IVC (cm) } \\
\hline $\begin{array}{c}\text { Mean } \pm \text { SD } \\
\text { Range }\end{array}$ & $\begin{array}{c}1.78 \pm 0.08 \\
1.7-1.9\end{array}$ & $\begin{array}{c}1.15 \pm 0.09 \\
1.0-1.3\end{array}$ & $\begin{array}{c}1.47 \pm 0.08 \\
1.3-1.6\end{array}$ & 282.019 & $0.000^{* *}$ & $\begin{array}{l}\mathrm{P}_{1}=0.000^{* *} \\
\mathrm{P}_{2}=0.000^{* *} \\
\mathrm{P}_{3}=0.000^{* *}\end{array}$ \\
\hline \multicolumn{7}{|c|}{ IVC change $(\mathrm{cm})$} \\
\hline $\begin{array}{c}\text { Mean } \pm \text { SD } \\
\text { Range }\end{array}$ & $\begin{array}{c}0.38 \pm 0.84 \\
0.3-0.5\end{array}$ & $\begin{array}{c}0.68 \pm 0.08 \\
0.5-0.8\end{array}$ & $\begin{array}{c}0.34 \pm 0.08 \\
0.2-0.5\end{array}$ & 154.233 & $0.000^{* *}$ & $\begin{array}{c}P_{1}=0.000^{* *} \\
P_{2}=0.076 \\
P_{3}=0.000^{* *}\end{array}$ \\
\hline
\end{tabular}

Table 3. Comparison of the changes in the number of B-lines in the studied groups.

\begin{tabular}{|c|c|c|c|c|c|c|}
\hline Variable & $\begin{array}{l}\text { Group 1 } \\
(n=12)\end{array}$ & $\begin{array}{l}\text { Group 2 } \\
(n=28)\end{array}$ & $\begin{array}{l}\text { Group } 3 \\
(n=48)\end{array}$ & F & $P$ value & L.S.D. \\
\hline \multicolumn{7}{|c|}{ No. of B-lines before } \\
\hline $\begin{array}{c}\text { Mean } \pm \text { SD } \\
\text { Range }\end{array}$ & $\begin{array}{c}10.17 \pm 1.12 \\
8-12\end{array}$ & $\begin{array}{c}4.89 \pm 0.88 \\
3-6\end{array}$ & $\begin{array}{c}4.35 \pm 0.91 \\
3-6\end{array}$ & 192.297 & $0.000^{\star \star}$ & $\begin{array}{l}P_{1}=0.000^{* *} \\
P_{2}=0.000^{* *} \\
P_{3}=0.017^{*}\end{array}$ \\
\hline \multicolumn{7}{|c|}{ No. of B-lines after } \\
\hline $\begin{array}{c}\text { Mean } \pm \text { SD } \\
\text { Range }\end{array}$ & $\begin{array}{c}4.00 \pm 0.74 \\
3-5\end{array}$ & $\begin{array}{c}2.04 \pm 0.58 \\
1-3\end{array}$ & $\begin{array}{c}1.88 \pm 0.61 \\
1-3\end{array}$ & 58.950 & $0.000^{* *}$ & $\begin{array}{c}P_{1}=0.000^{* *} \\
P_{2}=0.000^{* *} \\
P_{3}=0.275\end{array}$ \\
\hline \multicolumn{7}{|c|}{ change in No. of B-lines } \\
\hline $\begin{array}{c}\text { Mean } \pm \text { SD } \\
\text { Range }\end{array}$ & $\begin{array}{c}6.17 \pm 1.27 \\
3-8\end{array}$ & $\begin{array}{c}2.86 \pm 0.65 \\
2-4\end{array}$ & $\begin{array}{c}2.48 \pm 0.65 \\
1-4\end{array}$ & 115.187 & $0.000^{\star *}$ & $\begin{array}{l}P_{1}=0.000^{* *} \\
P_{2}=0.000^{* *} \\
P_{3}=0.039^{*}\end{array}$ \\
\hline \multicolumn{7}{|c|}{$\begin{array}{l}{ }^{*} \text { significant if } \mathrm{P}<0.05,{ }^{*} \text { highly significant if } \mathrm{P}<0.01, \mathrm{~F} \text { : ANOVA test, } \mathrm{LSD} \text { (least significant difference): } \\
\mathrm{P}_{1} \text { : Comparison between group } 1 \text { and } 2, \mathrm{P}_{2} \text { : Comparison between group } 1 \text { and } 3, \mathrm{P}_{3} \text { : Comparison between } \\
\text { group } 2 \text { and } 3 \text {. }\end{array}$} \\
\hline \multirow{2}{*}{\multicolumn{2}{|c|}{ Variable }} & \multicolumn{5}{|c|}{ B line change } \\
\hline & & & $\mathbf{R}$ & \multicolumn{3}{|c|}{$P$ Value } \\
\hline \multicolumn{2}{|c|}{ IVC change } & & 0.950 & \multicolumn{3}{|c|}{$0.007^{* *}$} \\
\hline \multicolumn{2}{|c|}{ UF volume } & & -0.347 & & 0.00 & $1^{* *}$ \\
\hline \multicolumn{2}{|c|}{ Weight } & & -0.113 & \multicolumn{3}{|c|}{0.292} \\
\hline \multicolumn{2}{|c|}{ IDWG } & & -0.342 & \multicolumn{3}{|c|}{$0.001 * *$} \\
\hline
\end{tabular}




\section{Continued}

\begin{tabular}{ccc}
\hline $\mathrm{Hb}$ & -0.140 & 0.192 \\
Albumin & -0.464 & $\mathbf{0 . 0 0 0 * *}$ \\
Creatinine & -0.459 & $\mathbf{0 . 0 0 0 * *}$ \\
$\mathrm{Kt} / \mathrm{V}$ & 0.157 & 0.143 \\
Endotheline & 0.733 & $\mathbf{0 . 0 0 0 * *}$ \\
BMI & -0.393 & $\mathbf{0 . 0 0 0 * *}$ \\
SBP & 0.199 & 0.063 \\
\hline
\end{tabular}

$\mathrm{r}$ is Pearson's correlation coefficient. * significant if $\mathrm{p}<0.05,{ }^{* *}$ highly significant if $\mathrm{p}<0.01$.

Table 5. Cut-off value of the number of pre-dialysis B-lines for predicting intradialytic hypertension.

\begin{tabular}{cccccc}
\hline AUC & Best cut off & Sensitivity & Specificity & P value & CI \\
\hline 0.979 & $\geq 5$ & $91.7 \%$ & $100 \%$ & $\mathbf{0 . 0 0 0 * *}$ & $0.904-0.999$ \\
\hline
\end{tabular}

** Highly significant if $\mathrm{p}<0.01$.

Table 6. Comparison of the IVC diameter changes before \& after intervention in group (1) patients.

\begin{tabular}{ccccc}
\hline Variable & $\begin{array}{c}\text { Group } 1^{\text {Before }} \\
(\mathrm{n}=12)\end{array}$ & $\begin{array}{c}\text { Group } 1^{\text {After }} \\
(\mathrm{n}=12)\end{array}$ & $\boldsymbol{t}$ test & P value \\
\hline \multicolumn{5}{c}{ IVC pre: } \\
\hline Mean \pm SD & $2.16 \pm 0.14$ & $1.73 \pm 0.11$ & \\
Range & $2-2.4$ & $1.6-1.9$ & 13.951 & $0.000^{* *}$ \\
\hline IVC post: & & \\
\hline Mean \pm SD & $1.78 \pm 0.08$ & $1.38 \pm 0.01$ & $0.000^{* *}$ \\
Range & $1.7-1.9$ & $1.2-1.5$ & 16.248 & \\
\hline
\end{tabular}

${ }^{* *}$ Highly significant if $\mathrm{p}<0.01$.

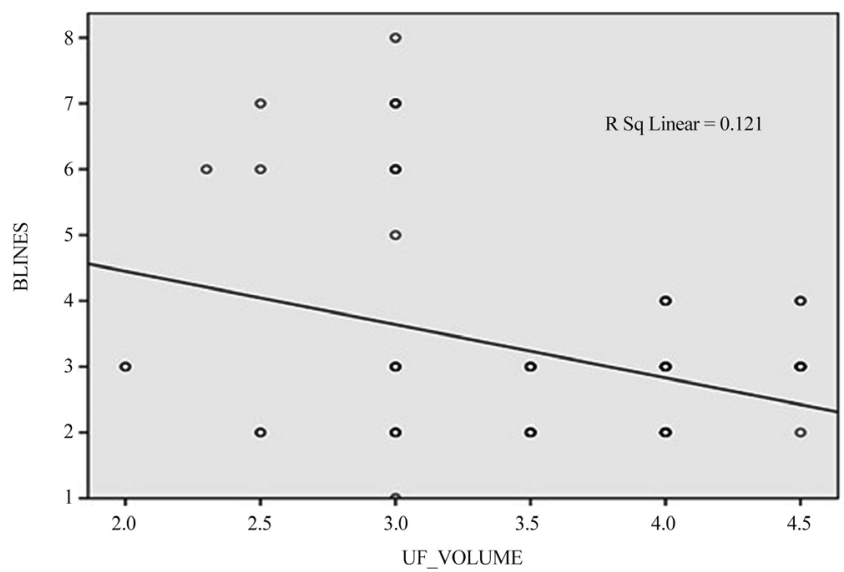

Figure 1. Correlation between pre-dialysis number of B-lines and UF volume. There was a statistically significant negative correlation between the number of pre-dialysis B-lines and UF volume $(\mathrm{p}<0.001, \mathrm{r}=-0.347)$. 


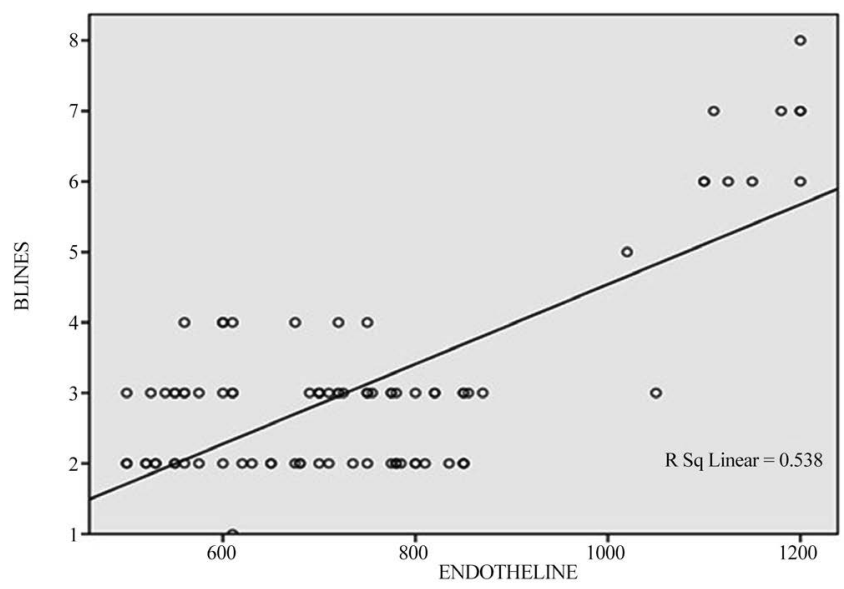

Figure 2. Correlation between pre-dialysis number of B-lines and ET-1. There was a statistically significant positive correlation between the number of pre-dialysis B-lines and ET-1 ( $p<0.000, r=0.733)$.

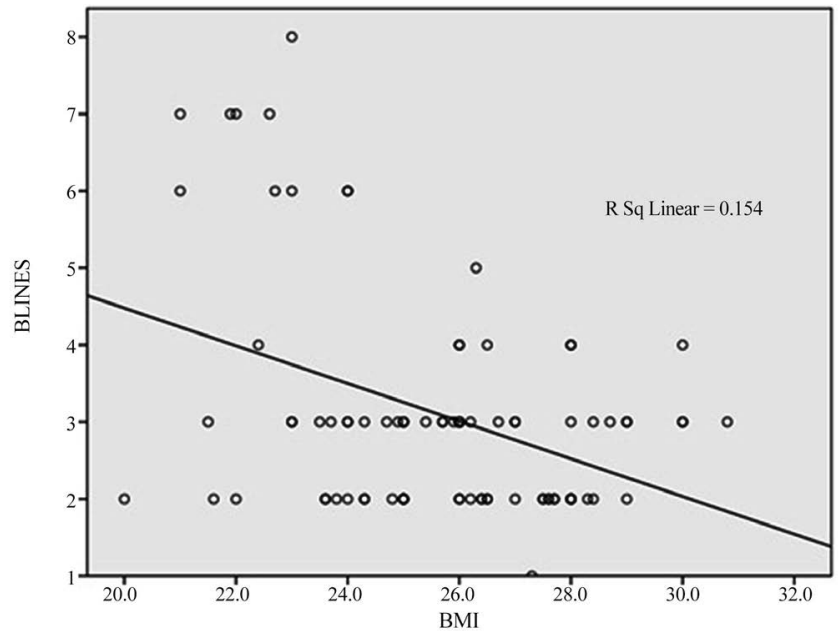

Figure 3. Correlation between pre-dialysis number of B-lines and BMI. There was a statistically significant negative correlation between the number of pre-dialysis B-lines and BMI $(\mathrm{p}=0.000, \mathrm{r}=-0.393)$.

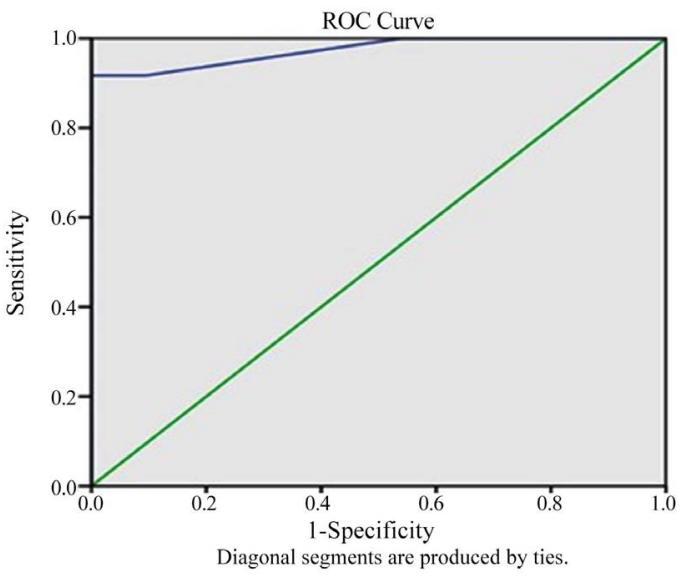

Figure 4. ROC curve analysis for pre-dialysis number of B-lines in prediction of intradialytic hypertension. 


\section{Discussion}

In ESRD patients on maintenance HD, hypertension is a main feature and more than $85 \%$ of new patients with ESRD present with hypertension [6]. Decrease of blood pressure (BP) in most HD patients is common, but some patients show a paradoxical increase in $\mathrm{BP}$ during $\mathrm{HD}$. This increase in $\mathrm{BP}$ during $\mathrm{HD}$ is known as intra-dialytic hypertension [7]. The exact pathogenesis of intra-dialytic hypertension is unknown. Several factors may be involved in the pathogenesis of IHTN, including extracellular fluid volume overload [8]. LUS is increasingly used nowadays for volume assessment through the analysis of B-line artifacts [4].

Due to the significant correlation between cardiovascular mortality and intra-dialytic hypertension and in view of the difficulty to manage this group of patients we aimed at this study to evaluate LUS as a non-invasive modality in assessment of ELW in patients with intra-dialytic hypertension.

The current study was carried out on 88 patients on regular HD divided into three groups. Group (1) HD patients with intra-dialytic hypertension $(\mathrm{n}=12)$, group (2) HD patients with intra-dialytic hypotension $(n=28)$ and group (3) HD patients with no blood pressure variabilities $(n=48)$.

In the current study there were no significant differences between the studied groups regarding age, gender, and the original kidney disease. The current study showed that 12 patients (13\%) had intra-dialytic hypertension which is matched with Inrig et al. [9]. who had a retrospective analysis of 438 prevalent HD participants enrolled in a controlled trial of blood volume monitoring, they found that $13.2 \%$ of participants had an increase in SBP $\geq 10 \mathrm{~mm} \mathrm{Hg}$ from pre- to post-dialysis. Also, Inrig et al. [10] in an analysis of $1748 \mathrm{HD}$ patients enrolled in the US Renal Data System (USRDS) Dialysis Morbidity and Mortality Wave II cohort, found that $12 \%$ showed $\geq 10 \mathrm{mmHg}$ increases in SBP from pre- to post-dialysis. Georgianos et al. [11] during their survey on HD patients, they founded that $8 \%$ of patients had an increase in MAP $\geq 15 \mathrm{~mm} \mathrm{Hg}$ during a 2-week period.

The current study revealed that group (1) had significantly low serum albumin, BMI and IDWG compared to the other groups. These patients do not undergo proper ultrafiltration during dialysis which subsequently leads to progressive volume accumulation and eventually leading to intra-dialytic hypertension. These data are consistent with the study of Georgianos et al. [11] which was conducted on $1748 \mathrm{HD}$ patients followed in USRDS Wave II, patients with $\geq 10$ $\mathrm{mm} \mathrm{Hg}$ intra-dialytic increases in SBP that had the following criteria: lower serum albumin levels, DBW and IDWG when compared with patients without intra-dialytic hypertension [11].

The present study revealed that $31 \%$ of patients had intra-dialytic hypotension. This group of patients had significantly increased DBW, BMI, IDWG and UF volume compared to the other groups. Consistent with these results, Kuipers et al. [12] showed that (20\% - 50\%) of HD patients develop intra-dialytic hypo- 
tension. This group of patients had significantly increased IDWG and UF volume. This can be explained by gaining too much weight between HD sessions. UF rate during HD sessions exceeds plasma refilling volume which leads to interrupted HD sessions and intradialytic hypotension [12].

In the current study we found significantly elevated serum ET-1 levels in patients with intra-dialytic hypertension, this result matches with Diaz et al. [13] who investigated 27 patients ( 9 patients had intra-dialytic hypertension, 9 patients had intra-dialytic hypotension, and 9 patients with stable intra-dialytic BP). The authors demonstrated that ET-1 levels were significantly increased in patients with intra-dialytic hypertension. Recently ElSharkawy et al. [14] demonstrated that ET-1 levels were significantly increased in HD patients with intra-dialytic hypertension and that and pre-dialysis ET-1 level had a significant moderate diagnostic performance in prediction of intra-dialytic hypertension.

The present study showed significantly increased number of pre-dialysis $(10.17 \pm 1.12)$ and post-dialysis $(4.00 \pm 0.74)$ B-lines as well as the change of B-lines number $(6.17 \pm 1.27)$ in group (1) compared with the other two groups. These data are consistent with a study by Liang et al. [15] in which their patients' B-line scores were (10 B-lines pre-dialysis and $4 \mathrm{~B}$-lines post-dialysis), with Trezzi et al. [16] (24 - 25 B-lines pre-dialysis and 9 - 10 post-dialysis) and with Vitturi et al. [17] (3.5 - 4 pre-dialysis and 1.7 - 3.1 post-dialysis). These variabilities in the number of B-lines are related to the patients' underlying cardiac condition. But there is consensus on positive correlation between high number of B-lines and intra-dialytic hypertension. In this study, we excluded patients with heart failure NYHA class III or IV.

Assessment of IVC diameter by ultrasound and the derived collapsibility index have been used to predict volume status. However, they can be used to predict intravascular volume and not real tissue hydration, in addition to the significant inter-operator variability and the marked limitations in cases of right-sided cardiac failure or diastolic dysfunction [18]. The current study showed that pre and post-dialysis IVC diameters were significantly increased in group (1) compared to the other two groups. These data are correlated with the expected hypervolemia in this sector of patients and matched with the higher number of B-lines.

On the other hand, there were significantly low post-dialysis IVC diameters in group (2) compared with the other two groups, these data are matched with excessive UF in this group leading to decreased intravascular volume. Imbalance between intravascular volume and capillary refill leads to hypotension. In spite of the low IVC diameter in group (2), the number of pre-dialysis B-lines in this group was significantly higher than group (3) and the number of post-dialysis B-lines were not significantly lower than the other groups, indicating that lung ultrasound is not sensitive in detection of hypovolemia.

In the current work, we demonstrated a statistically significant positive correlation between the number of pre-dialysis B-lines and IVC diameter. Consistent with this, Basso et al. [19] found that B-line score is positively associated with 
IVC diameter divided by body surface area which is known as (indexed IVC diameter) in inspiration (both pre and post-dialysis) and expiration (only pre-dialysis) and with the IVC collapsibility index (only pre-dialysis). Vitturi et al. [17] found a positive relationship between B-lines changes during dialysis and changes in inspiratory and expiratory IVC diameters, but there was no relation with changes in the collapsibility index. There was also a statistically significant positive correlation between the number of pre-dialysis B-lines and ET-1 in group (1). Matching with this, ElSharkawy et al. demonstrated positive correlation between pre-dialysis ET-1 and intra-dialytic hypertension [14].

We also demonstrated statistically significant negative correlations between the number of pre-dialysis B-lines and UF volume, IDWG, Albumin, Creatinine \& BMI in group (1). Nobel et al. [20] were the first to show that there is an association between the change in B-lines number and UF volume during $\mathrm{HD}$, with a decrease of $2.7 \mathrm{~B}$ lines for each $500 \mathrm{~mL}$ UF.

For patients in group (1) we gradually reduced their DBW over many HD sessions trough revision of their diet, fluid intake, medications and UF volume in parallel with follow up LUS till we reached our cut-off value (number of pre-dialysis B-lines $<5$ ). At that point, we re-evaluated these patients and found that 9 patients out of the 12 (75\%) did not show intra-dialytic hypertension. Also, there were significant reductions in the pre and post-dialysis IVC diameters when compared to the previous results.

\section{Conclusion}

Based on the previous results, we can conclude that LUS can be considered as a reliable tool for detection of subclinical fluid overload in HD patients mainly with intra-dialytic hypertension. A cut-off value of $\geq 5$ pre-dialysis B-lines can be used for prediction of intra-dialytic hypertension with good sensitivity and specificity. We hope that serial LUS examination for our regular HD patients with intra-dialytic hypertension might be of help in proper management of this extremely challenging problem.

\section{Conflicts of Interest}

The authors declare no conflicts of interest regarding the publication of this paper.

\section{References}

[1] Van Buren, P.N., Kim, C., Toto, R.D. and Inrig, J.K. (2012) The Prevalence of Persistent Intradialytic Hypertension in a Hemodialysis Population with Extended Follow-Up. The International Journal of Artificial Organs, 35, 1031-1038. https://doi.org/10.1177/039139881203501201

[2] Van Buren, P.N., Zhou, Y., Neyra, J.A., Xiao, G., Vongpatanasin, W., Inrig, J.K. and Toto, R. (2016) Extracellular Volume Overload and Increased Vasoconstriction in Patients with Recurrent Intradialytic Hypertension. Kidney and Blood Pressure Research, 41, 802-814. https://doi.org/10.1159/000450565 
[3] Park, J., Rhee, C., Sim, J., et al. (2013) A Comparative Effectiveness Research Study of the Change in Blood Pressure during Hemodialysis Treatment and Survival. Kidney International, 84, 795-802. https://doi.org/10.1038/ki.2013.237

[4] Zoccali, C. (2017) Lung Ultrasound in the Management of Fluid Volume in Dialysis Patients: Potential Usefulness. Seminars in Dialysis, 30, 6-9. https://doi.org/10.1111/sdi.12559

[5] Rubinger, D., Backenroth, R. and Sapoznikov, D. (2012) Sympathetic Activation and Baroreflex Function during Intradialytic Hypertensive Episodes. PLoS ONE, 7, e36943. https://doi.org/10.1371/journal.pone.0036943

[6] Bakris, G.L., Burkart, J.M., Weinhandl, E.D., McCullough, P.A. and Kraus, M.A. (2016) Intensive Hemodialysis, Blood Pressure, and Antihypertensive Medication Use. American Journal of Kidney Diseases, 68, S15-S23. https://doi.org/10.1053/j.ajkd.2016.05.026

[7] Webster, A.C., Nagler, E.V., Morton, R.L. and Masson, P. (2017) Chronic Kidney Disease. The Lancet, 389, 1238-1252. https://doi.org/10.1016/S0140-6736(16)32064-5

[8] Rocha, A. (2016) Pathogenesis and Treatment Options for Intradialytic Hypertension. Panminerva Medica, 58, 237-241.

[9] Inrig, J.K., Patel, U.D., Toto, R.D., Reddan, D.N., Himmel, F.J., Lindsay, R.M., Stivelman, J., Winchester, J.F. and Szczech, L.A. (2009) Decreased Pulse Pressure during Hemodialysis Is Associated with Improved 6-Month Outcome. Kidney International, 76, 1098-1107. https://doi.org/10.1038/ki.2009.340

[10] Inrig, J.K., Patel, U.D., Toto, R.D. and Szczech, L.A. (2009) Association of Blood Pressure Increases during Hemodialysis with 2-Year Mortality in Incident Hemodialysis Patients: A Secondary Analysis of the Dialysis Morbidity and Mortality Wave 2 Study. American Journal of Kidney Diseases, 54, 881-890. https://doi.org/10.1053/j.ajkd.2009.05.012

[11] Georgianos, P.I., Sarafidis, P.A. and Zoccali, C. (2015) Intradialysis Hypertension in End-Stage Renal Disease Patients: Clinical Epidemiology, Pathogenesis, and Treatment. Hypertension, 66, 456-463. https://doi.org/10.1161/HYPERTENSIONAHA.115.05858

[12] Kuipers, J., Oosterhuis, J.K., Krijnen, W.P., Dasselaar, J.J., Gaillard, C.A., Westerhuis, R. and Franssen, C.F. (2016) Prevalence of Intradialytic Hypotension, Clinical Symptoms and Nursing Interventions-A Three-Months, Prospective Study of 3818 Haemodialysis Sessions. BMC Nephrology, 17, Article No. 21. https://doi.org/10.1186/s12882-016-0231-9

[13] Diaz, H.J., Bryan, J., Arraut, J.C., Betancourt, J., Morales, C.M. and Cangiano, J.L. (2016) Intradialytic Hypertension/Hypotension and Mortality in San Juan, Puerto Rico. Boletin de la Asociacion Medica de Puerto Rico, 108, 77-80.

[14] ElSharkawy, M., Abou Zaghla, H., Emara, A.A., El-Emary, Y. and Hassan, M. (2020) Intradialytic Changes in Endothelin-1 Level and Its Relationship with Intradialytic Hypertension. Journal of the Egyptian Society of Nephrology and Transplantation, 20, 91-97. https://doi.org/10.4103/jesnt.jesnt $37 \quad 19$

[15] Liang, X.K., Li, L.J., Wang, X.H., Wang, X.X., Wang, Y.D. and Xu, Z.F. (2019) Role of Lung Ultrasound in Adjusting Ultrafiltration Volume in Hemodialysis Patients. Ultrasound in Medicine \& Biology, 45, 732-740. https://doi.org/10.1016/j.ultrasmedbio.2018.10.025

[16] Trezzi, M., Torzillo, D., Ceriani, E., Costantino, G., Caruso, S., Damavandi, P.T. and Cogliati, C. (2013) Lung Ultrasonography for the Assessment of Rapid Extravascu- 
lar Water Variation: Evidence from Hemodialysis Patients. Internal and Emergency Medicine, 8, 409-415. https://doi.org/10.1007/s11739-011-0625-4

[17] Vitturi, N., Dugo, M., Soattin, M., Simoni, F., Maresca, L., Zagatti, R. and Maresca, M.C. (2014) Lung Ultrasound during Hemodialysis: The Role in the Assessment of Volume Status. International Urology and Nephrology, 46,169-174. https://doi.org/10.1007/s11255-013-0500-5

[18] Coiro, S., Rossignol, P., Ambrosio, G., Carluccio, E., Alunni, G., Murrone, A. and Girerd, N. (2015) Prognostic Value of Residual Pulmonary Congestion at Discharge Assessed by Lung Ultrasound Imaging in Heart Failure. European Journal of Heart Failure, 17, 1172-1181. https://doi.org/10.1002/ejhf.344

[19] Basso, F., Milan Manani, S., Cruz, D.N., Teixeira, C., Brendolan, A., Nalesso, F., Zanella, M. and Ronco, C. (2013) Comparison and Reproducibility of Techniques for Fluid Status Assessment in Chronic Hemodialysis Patients. Cardiorenal Medicine, 3, 104-112. https://doi.org/10.1159/000351008

[20] Noble, V.E., Murray, A.F., Capp, R., Sylvia-Reardon, M.H., Steele, D.J.R. and Liteplo, A. (2009) Ultrasound Assessment for Extravascular Lung Water in Patients Undergoing Hemodialysis. Time Course for Resolution. Chest, 135, 1433-1439.

https://doi.org/10.1378/chest.08-1811 